Note

\title{
Reaction of dwarf cashew clones to Colletotrichum gloeosporioides isolates in controlled environment
}

\author{
Ana Maria Queijeiro López ${ }^{1 *}$; John Alexander Lucas²,3 \\ ${ }^{1}$ UFAL/Instituto de Quimica e Biotecnologia, BR 104, km 97N - 57072-970 - Maceió, AL - Brasil. \\ ${ }^{2} I A C R$-Long Ashton Research Station, Department of Agricultural Sciences, University of Bristol, Long Ashton, \\ Bristol BS41 9AF, UK. \\ ${ }^{3}$ IACR-Rothamsted, Harpenden, Herts AL5 2JQ, UK. \\ *Corresponding author <amql@qui.ufal.br>
}

\begin{abstract}
The cashew (Anacardium occidentale L.) crop is an important source of income for the population of the Brazilian Northeast, and anthracnose disease caused by Colletotrichum gloeosporioides leads to significant production loss. However, there is little information on either the host resistance or the variation in the aggressiveness of the pathogen under controlled environment. The reaction of commercial (CCP-06, CCP09, CCP-76 and CCP-1001) and one non-commercial (CAP-14) dwarf cashew clones was assessed against 36 isolates of this fungus controlled environmental conditions. All the isolates, including those from hosts other than cashew, were able to cause lesions on leaves and stems of most clones, albeit to different degrees. Clone CCP-06 was the most susceptible, while clone CCP-1001 showed a level of resistance to a number of the isolates, including isolate 905, while isolates 910 and 912 were aggressive to all clones. Injury increased the susceptibility of the clones to all isolates, indicating that resistance also might be associated with structural barriers that hinder penetration. Ripened cashew apples (8-week-old), of commercial clones were susceptible to isolates 905 and 910. Immature pseudo-fruits (2-week-old), with exception of clone CCP-76 which was susceptible to both isolates showed resistance against these isolates, suggesting the presence of structural and chemical barriers. Developed nuts (8-week-old), however, were more resistant than immature nuts (2-weekold) to both isolates, probably due to their thicker exocarp cuticle and reduced number of stomatal pores.

Key words: Anacardium occidentale, anthracnose, resistance, aggressiveness
\end{abstract}

\section{Reação de clones de cajueiro-anão a isolados de Colletotrichum gloeosporioides em ambiente controlado}

\begin{abstract}
RESUMO: A cultura de caju (Anacardium occidentale L.) é uma fonte de renda importante para a população do Nordeste brasileiro, sendo a antracnose causada por Colletotrichum gloeosporioides a doença que mais conduz a perdas de sua produção. Entretanto, há pouca informação para a resistência desse hospedeiro ou para a variação na agressividade do patógeno em ambiente controlado. A reação de clones comerciais (CCP-06, CCP-09, CCP-76 e CCP-1001) e um não comercial (CAP-14) de cajueiros anão-precoce, contra 36 isolados desse fungo, foi avaliada sob condições controladas. Todos os isolados, incluindo os provenientes de diferentes hospedeiros, foram capazes de causar lesões sobre folhas e hastes da maioria dos clones, ainda que em graus diferenciados. O clone CCP-06 foi o mais suscetível, enquanto o clone CCP-1001 foi resistente a mais isolados, incluindo o 905, enquanto os isolados 910 e 912 foram agressivos a todos os clones testados. A injúria mecânica das folhas aumentou a suscetibilidade dos clones a todos os isolados, indicando que a resistência pode também estar associada a barreiras estruturais que impedem a penetração. Os pseudofrutos amadurecidos (8 semanas) dos clones comerciais avaliados, foram suscetíveis a ambos os isolados testados (905 e 910), mas os jovens (2 semanas), com exceção daqueles do clone CCP-76, suscetíveis aos dois isolados, apresentaram resistência a ambos, sugerindo a ação de obstáculos estruturais e químicos diferenciados. As castanhas desenvolvidas (8 semanas), no entanto, foram mais resistentes a ambos os isolados do que as jovens (2 semanas), talvez devido à espessa cutícula do exocarpo e baixo número de estômatos.

Palavras-chave: Anacardium occidentale, antracnose, resistência, agressividade
\end{abstract}

\section{Introduction}

Until three decades ago, the production of cashew (Anacardium occidentale L.) in Brazil was based on seed propagated trees of the "Common" or "Giant" type, which lack uniformity for commercial characteristics. Such trees were grown widely-spaced in a semi-wild state and this, combined with the high level of heterozygosity in the crop, restricted the amount of disease present. With the introduction of vegetatively-propagated dwarf clones of cashew, which are more uniform for agronomic characteristics (Barros and Crisóstomo, 1995), outbreaks of several diseases have become more prevalent in commercial orchards (Cardoso et al., 1999). 
Anthracnose disease, caused by the fungus Colletotrichum gloeosporioides (Penz.) Penz. and Sacc. [the anamorphic stage of Glomerella cingulata (Stoneman) Sp. and Schrenk], is widely distributed throughout the cashew-growing areas of the world, and has caused economic losses also in Brazil (Freire et al., 2002). The only practical management strategy for this pathogen involves general sanitation practices and chemical control (Cardoso et al., 1999), but the preferred option should be the use of clones with improved resistance to the pathogen. However, any breeding programme must take into account the variation in the pathogen population.

There is little information on either host resistance or pathogenic variation in the cashew anthracnose pathosystem under controlled environment. Therefore, tests under controlled conditions were carried out on injured and not injured leaves, stems and fruits of different dwarf cashew clones, with the purpose to verify: i) their reaction against 36 distinct Colletotrichum isolates, from cashew and associated plants from different regions of Brazil; and ii) the variability between the tested isolates.

\section{Material and Methods}

All the experiments using cashew leaves/stems were carried out in Bristol-UK, $51^{\circ} 25^{\prime} \mathrm{N}$; $2^{\circ} 39^{\prime} \mathrm{W}$; and the altitude is $27 \mathrm{~m}$. Experiments using cashew fruits (nuts) and pseudo-fruits (apples) were carried out in the research station of Pacajús, state of Ceará, Brazil, $04^{\circ} 10^{\prime}$; $38^{\circ} 27^{\prime} \mathrm{W}$; and the altitude is $60 \mathrm{~m}$.

\section{Fungal isolates and inoculum production}

The source of the 36 isolates of C. gloeosporioides studied is described in Table 1. Spores were produced by subculturing isolates in $100 \mathrm{~mL}$ Colletotrichum medium (CM) (Mathur et al., 1950) dispensed in $250 \mathrm{~mL}$ flasks. Spore suspensions were obtained by adding ca. $20 \mathrm{~mL}$ sterile distilled deionized water (SDW) to 7 days old flask cultures and shaking. All isolates were singlespored prior to experimental use.

\section{Cashew clones}

Seeds of the commercial cashew clones CCP-06, CCP-09, CCP-76, CCP-1001, and the experimental clone CAP-14 (derived from a mutant of CCP-76) were supplied by CNPAT/EMBRAPA, and stored in a cold room $\left(10^{\circ} \mathrm{C}\right)$ at the MPPD/LARS. Seeds were sown in a soil-sand-peat moss mixture $(1: 1: 1$ enriched with $2.5 \mathrm{~kg}$ $\mathrm{m}^{-3}$ of triple superphosphate and $1 \mathrm{~kg} \mathrm{~m}^{-3}$ of potassium chloride, $\mathrm{pH} 5.5)$ in $2 \mathrm{~L}$ plastic pots. The pots were maintained in a controlled environment chamber $(16 \mathrm{~h}$ light

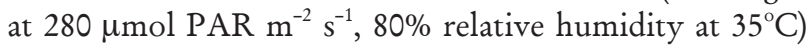
and were watered daily. After 10-15 days, when the seedlings emerged, the temperature of the chamber was reduced to $25^{\circ} \mathrm{C}$. Forty five-day-old seedlings were used for the inoculation experiments.

\section{Fruit material}

Intact cashew apples and nuts were harvested at different maturation stages (1-9 weeks) from commercial clones in experimental field plots of Pacajus, CE, Brazil, and taken to the laboratory for immediate inoculation tests.

\section{Pathogenicity Assays on Stem Segments and Leaves}

Stem segments bordering the youngest leaves, and the first and second youngest fully-expanded and intact leaves from 45-day-old plants were excised and the cut ends of the excised tissue sealed with warm, molten paraffin wax. The stems segments $(c a .5 \mathrm{~cm})$ were arranged on aluminium supports within plastic boxes $(20 \times 12 \times 4$ $\mathrm{cm})$ lined with moist filter paper. Excised leaves were placed flat on square propylene sheets inside transparent plastic boxes $(24 \times 24 \times 2 \mathrm{~cm})$ lined with moist tissue paper. The leaves were wounded or maintained intact prior to inoculation. For the wounding treatment, ten parallel incisions, sufficient to penetrate the epidermis, were made with sterile forceps on the adaxial or abaxial surface of leaves. Drops $(10 \mathrm{~mL})$ of conidial suspensions $\left(10^{6}\right.$ spores $\left.\mathrm{mL}^{-1}\right)$ were then placed, with the aid of a microdispenser (EDP-1, Rainin Instrument Co.) at intervals of $1 \mathrm{~cm}$, on the stems or on either side of the mid-vein of the adaxial or abaxial surface of the leaf lamina. The plant material was incubated in a controlled environment cabinet $\left[25^{\circ} \mathrm{C}, 100 \%\right.$ relative humidity (r.h.), for $24 \mathrm{~h}$ in the dark, followed by a photoperiod

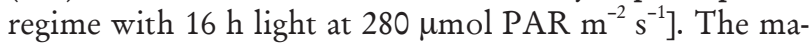
terial was evaluated for both symptom type and disease severity 2-7 days after inoculation. Symptom types were scored on a $0-5.0$ scale, where $0=$ no macroscopic symptoms; 1 = few small flecks $(1 \mathrm{~mm}) ; 2$ = flecks between $2-3 \mathrm{~mm} /$ limited lesions; $3=$ many coalescent flecks, lesions between $4-7 \mathrm{~mm} ; 4=$ water-soaked lesions, larger than $7 \mathrm{~mm} ; 5=$ spreading coalescent lesions with sporulation. For final tabulation of the data, symptom types were categorized into three broad reaction classes: $\mathrm{R}=$ resistant (scores $0-2) ; \mathrm{M}=$ moderately resistant (scores 2.1-3.0) and $\mathrm{S}=$ susceptible (scores 3.15.0). Disease severity (whole leaf) was scored on a $0-5$ scale, where $0=$ no necrotic tissue $(\mathrm{NT}) ; 1=\leq 5 \% \mathrm{NT}$; $2=6-20 \% \mathrm{NT} ; 3=21-35 \% \mathrm{NT} ; 4=36-60 \% \mathrm{NT} ; 5=$ $61-100 \%$ NT.

The factorial experiment consisted of a completely random design, for each clone-isolate combination, involving ten stem segments and three leaves for each position (first and second) and inoculated surface (abaxial or adaxial), and it was repeated three times. Equal number of stem segments and leaves were treated in the same way with sterile distilled water. The data were transformed to $\sqrt{x+0.5}$ for analysis of variance and comparison between the means by the LSD test $(p \leq$ 0.05).

Subsequently, three isolates $(905,910$, and 912) that were able to cause disease for all the clones, or that were unable to do it for at least one of them, were chosen for further study on attached leaves. Conidial suspensions $\left(10^{6}\right.$ spores $\left.\mathrm{mL}^{-1}\right)$ of these isolates were sprayed on leaves of 45-day-old plants (three per clone for each isolate). Inoculated plants were enclosed in wet plastic bags and 
Table 1 - Colletotrichum gloeosporioides isolates used in this study.

\begin{tabular}{|c|c|c|c|}
\hline Isolates(LARS) & Origin & Infected Organ & Locality \\
\hline 905 & Rubus brasiliensis & Leaf & Maceió - Alagoas ${ }^{1}$ \\
\hline 906 & Spondias purpurea L. & Leaf & Maceió - Alagoas ${ }^{1}$ \\
\hline 907 & Carica papaya L. & Leaf & Maceió - Alagoas ${ }^{1}$ \\
\hline 908 & Dioscorea sp. & Leaf & Maceió - Alagoas ${ }^{1}$ \\
\hline 909 & Malpigbia glabra L. & Leaf & Maceió - Alagoas ${ }^{1}$ \\
\hline 910 & Anacardium occidentale L. & Leaf & Maceió - Alagoas ${ }^{1}$ \\
\hline 911 & Anacardium occidentale L. & pseudo-fruit & Maceió - Alagoas ${ }^{1}$ \\
\hline 912 & Anacardium occidentale L. & nut & Cruz das Almas - Bahia ${ }^{1}$ \\
\hline 913 & Anacardium occidentale L. & pseudo-fruit & Cruz das Almas - Bahia ${ }^{1}$ \\
\hline 914 & Anacardium occidentale L. & Leaf & Conceição do Almeida-Bahia ${ }^{1}$ \\
\hline 915 & Anacardium occidentale L. & flower & Praia do Forte - Bahia ${ }^{1}$ \\
\hline 916 & Anacardium occidentale L. & Leaf & Indiaroba - Sergipe ${ }^{1}$ \\
\hline 917 & Anacardium occidentale L. & Leaf & Penedo - Alagoas ${ }^{1}$ \\
\hline 918 & Anacardium occidentale L. & Leaf & Maceió - Alagoas ${ }^{1}$ \\
\hline 919 & Anacardium occidentale L. & Leaf & Marechal Deodoro - Alagoas ${ }^{1}$ \\
\hline 920 & Anacardium occidentale L. & Leaf & Marechal Deodoro - Alagoas ${ }^{1}$ \\
\hline 921 & Anacardium occidentale L. & Leaf & Recife - Pernambuco ${ }^{2}$ \\
\hline 922 & Anacardium occidentale L. & pseudo-fruit & Belém - Pará ${ }^{3}$ \\
\hline 923 & Anacardium occidentale L. & Leaf & Fortaleza - Ceará ${ }^{3}$ \\
\hline 924 & Anacardium occidentale L. & Leaf & Pacajus - Ceará ${ }^{3}$ \\
\hline 925 & Anacardium occidentale L. & pseudo-fruit & Piracicaba - São Paulo ${ }^{3}$ \\
\hline 926 & Anacardium occidentale L. & Leaf & Cruz das Almas - Bahia ${ }^{3}$ \\
\hline 927 & Anacardium occidentale L. & pseudo-fruit & Fortaleza - Ceará ${ }^{3}$ \\
\hline 928 & Anacardium occidentale L. & pseudo-fruit & Brasília (DF) - Goiás ${ }^{3}$ \\
\hline 929 & Anacardium occidentale L. & pseudo-fruit & Pacajus - Ceará ${ }^{4}$ \\
\hline 930 & Anacardium occidentale L. & Leaf & Goiana - Pernambuco ${ }^{4}$ \\
\hline 931 & Anacardium occidentale L. & Leaf & Recife - Pernambuco ${ }^{4}$ \\
\hline 932 & Anacardium occidentale L. & Leaf & Fortaleza - Ceará ${ }^{4}$ \\
\hline 933 & Anacardium occidentale L. & Leaf & Areia - Pernambuco ${ }^{4}$ \\
\hline 934 & Anacardium occidentale L. & Leaf & Natal - Rio Grande do Norte \\
\hline 935 & Anacardium occidentale L. & Leaf & Recife - Pernambuco ${ }^{4}$ \\
\hline 936 & Anacardium occidentale L. & Leaf & Maceió - Alagoas ${ }^{4}$ \\
\hline 937 & Anacardium occidentale L. & Leaf & Olinda - Pernambuco ${ }^{4}$ \\
\hline 938 & Anacardium occidentale L. & Leaf & João Pessoa - Paraíba ${ }^{4}$ \\
\hline 939 & Anacardium occidentale L. & Leaf & Manaus - Amazonas 5 \\
\hline 940 & Anacardium occidentale L. & Leaf & Pacajus - Cearás \\
\hline
\end{tabular}

Isolates were provided in 1996 by : ${ }^{1}$ Prof. Dr. Eurico Lemos, “Centro de Ciências Agrárias - UFAL”, Maceió/AL; ${ }^{2}$ Dr. M.B. Figueiredo, "Seção de Micologia - Instituto Biológico de São Paulo", SP; ${ }^{3}$ Dr. E.E. Bach, "Seção de Bioquímica Vegetal - Instituto Biológico de São Paulo", SP; ${ }^{4}$ Prof. Dr. M. Menezes, "Departamento de Fitossanidade - UFRPe”, Recife/Pe; ${ }^{5}$ Dr. F.P. Freire, "Centro Nacional de Pesquisa da Agroindústria Tropical - EMBRAPA”, Fortaleza/CE.

incubated in a controlled environment cabinet as described above. Control plants were sprayed with sterilized deionised water. After 48 hours the plastic bags were removed and the plants observed daily for 10 days. The symptoms were scored as described above. The experiment consisted of a completely random design, with three repetitions for each assay. The data were also trans- formed to $\sqrt{x+0.5}$ for analysis of variance and comparison of the average scores by the LSD test $(p \leq 0.05)$.

Differences in virulence among isolates were examined by comparing the number of clones on which isolates induced symptoms. Aggressiveness among the isolates was measured by comparing the variation in the degree of symptoms (mean disease severity) on the 
cashew clones which were susceptible to all pathogen isolates. The LSD test $(p \leq 0.05)$ was used to compare every possible pair of treatment means and rank the relative aggressiveness among the isolates.

\section{Pathogenicity Assays on Pseudo-fruits and Fruits}

Three whole apples and attached nuts of each clone, in different stages of maturation (three per stage), were surface disinfected by consecutive immersion for $5 \mathrm{~min}$ in $75 \%$ (v:v) EtOH, 10 min in $65 \% \mathrm{NaOCl}(10 \%$ available chlorine) and $1 \mathrm{~min}$ in $75 \% \mathrm{EtOH}$. The samples of each clone were rinsed in sterilized distilled water, dried with sterile tissue paper, placed inside plastic boxes $(50 \times 30$ $\times 20 \mathrm{~cm}$ ) lined with moist tissue paper, and axially marked with black permanent ink using a lumocolor pen. Drops $(10 \mathrm{~mL})$ of conidial suspension $\left(10^{6} \mathrm{~mL}^{-1}\right)$ of LARSisolates 905 and 910 were placed at $1 \mathrm{~cm}$ intervals onto an area of $1.5 \mathrm{~cm}$ of the axial line of the surface of apples and nuts. Each side of the axial line was inoculated with one different isolate. The boxes were then closed and incubated in a controlled environment room $\left(25^{\circ} \mathrm{C}, 100 \%\right.$ r.h., for $24 \mathrm{~h}$ in the dark followed by a photoperiod with

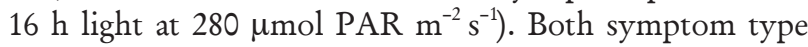
and disease severity were evaluated as described before, 96 hours after inoculation. The experiment (completely random design) was repeated three times and the data were transformed to for analysis of variance and comparison of the average scores by the LSD test $(p \leq 0.05)$.

\section{Results and Discussion}

The reaction of intact leaves of all clones varied, suggesting differences in host susceptibility, irrespective of the C. gloeosporioides isolate (Table 2). Clone CCP-1001 was resistant to $58 \%$ of the isolates and moderately-resistant to $22 \%$ of them, while clone CCP-06 was susceptible to $97.2 \%$ of the isolates. The non commercial clone CAP-14 was resistant and moderately-resistant to $30.5 \%$ and $38.8 \%$ of the isolates, respectively. The clones CCP09 and CCP-76 were respectively susceptible to $c a .81$ and $67 \%$ of the isolates. The same results were seen on the stem segments (data not shown). This suggests that under field conditions, none of the clones would remain free of anthracnose indefinitely.

Virulence of the pathogen isolates was determined by comparing the number of host genotypes on that they produced symptoms of an interaction considered as compatible (susceptibility). Isolates 910, 912, 913, 919, 932 and 939 induced symptoms in all the clones, while their aggressiveness (disease severity) varied slightly (Table 2). The remaining 30 isolates were pathogenic to some of the different clones, while isolates 926, 927, 930 and 936 were only pathogenic on CCP-06. All clones were moderately-resistant to isolate 922 . Analysis of the transformed data (Table 3) indicated differences $(p \leq 0.05)$ in the relative susceptibility of the different hosts, between isolates and in the host-isolate interaction. After seven days, the disease reaction type of the first and second young leaves of all the clones to each isolate was gener- ally only slightly influenced by the surface inoculated (data not shown).

The younger first leaves of cashew seedlings were more susceptible than the older second leaves (Figure 1). This result is similar to observations on other hostColletotrichum combinations (Bentes and Matsuoka, 2002; Waller, 1992). Disease was also less severe in attached than in detached leaves, although host reaction among the clones was not modified (Figure 1). Wounding invariably gave rise to necrotic lesions, even in clone-isolate combinations that were resistant when leaves were intact (Figure 2). Such resistance to C. gloeosporioides may therefore be associated with structural barriers that hinder penetration at the epidermal level.

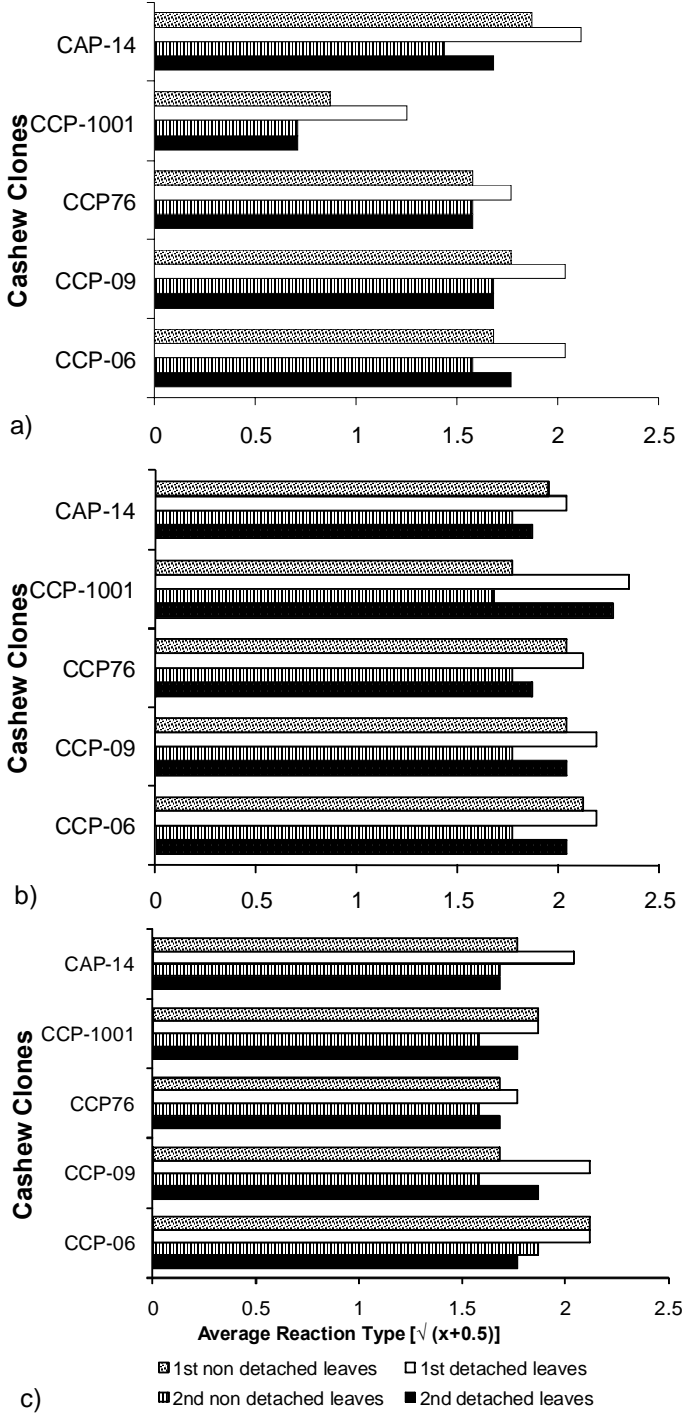

Figure 1 - Disease severity on the first (1st) and second (2nd) intact (detached and attached) leaves of Anacardium occidentale clones, $120 \mathrm{~h}$ after inoculation (abaxial surface) with LARS isolates of Colletotrichum gloeosporioides: a) 905; b) 910; c) 912. Averages (three experiments in triplicates) of the transformed data $\leq 1.58$ (type 2) were scored as resistant; from 1.58 to 1.87 (types 2 and 3 ) as moderately resistant, and $>1.87$ (type 3 ) as susceptible 
Table 2 - Reaction classes (RC) ${ }^{1}$ and disease severity scores (DS) ${ }^{2}$ on young detached first leaves of different clones of Anacardium occidentale, $120 \mathrm{~h}$ after inoculation (abaxial surface) with different isolates of Colletotrichum gloeosporioides, in a controlled environment.

\begin{tabular}{|c|c|c|c|c|c|c|c|c|c|c|}
\hline \multirow{2}{*}{$\begin{array}{l}\text { Isolates } \\
\text { (LARS) }\end{array}$} & \multicolumn{2}{|c|}{ ССР-06 } & \multicolumn{2}{|c|}{ ССР-09 } & \multicolumn{2}{|c|}{ ССР-76 } & \multicolumn{2}{|c|}{ CСР-1001 } & \multicolumn{2}{|c|}{ CAP-14 } \\
\hline & $\mathrm{RC}$ & DS & $\mathrm{RC}$ & DS & $\mathrm{RC}$ & DS & $\mathrm{RC}$ & DS & $\mathrm{RC}$ & DS \\
\hline 905 & S & $3.7 \pm 0.6$ & S & $3.7 \pm 0.6$ & S & $3.3 \pm 0.6$ & $\mathrm{R}$ & $1.0 \pm 0$ & S & $4.3 \pm 0.6$ \\
\hline 906 & S & $4.0 \pm 0$ & S & $4.0 \pm 0$ & S & $5.0 \pm 0$ & M & $3.0 \pm 0$ & S & $4.0 \pm 0$ \\
\hline 907 & S & $4.0 \pm 0$ & $\mathrm{R}$ & $1.0 \pm 0$ & S & $4.3 \pm 0.6$ & $\mathrm{R}$ & $0.3 \pm 0.6$ & S & $3.7 \pm 0.6$ \\
\hline 908 & S & $4.7 \pm 0.6$ & S & $5.0 \pm 0$ & S & $4.7 \pm 0.6$ & $\mathrm{R}$ & $1.7 \pm 0.6$ & M & $3.0 \pm 0$ \\
\hline 909 & S & $3.7 \pm 0.6$ & S & $4.0 \pm 0$ & S & $3.7 \pm 0.6$ & $\mathrm{R}$ & $1.0 \pm 0$ & $\mathrm{R}$ & $1.7 \pm 0.6$ \\
\hline 910 & S & $4.3 \pm 0.6$ & S & $4.3 \pm 0.6$ & S & $4.0 \pm 0$ & S & $5.0 \pm 0$ & S & $4.0 \pm 0$ \\
\hline 911 & S & $4.7 \pm 0.6$ & S & $4.7 \pm 0.6$ & M & $3.0 \pm 0$ & $\mathrm{R}$ & $1.0 \pm 0$ & M & $3.0 \pm 0$ \\
\hline 912 & S & $5.0 \pm 0$ & S & $4.0 \pm 0$ & S & $4.3 \pm 0.6$ & S & $4.3 \pm 0.6$ & $\mathrm{~S}$ & $3.3 \pm 0.6$ \\
\hline 913 & S & $4.0 \pm 0$ & S & $4.0 \pm 0$ & S & $4.7 \pm 0.6$ & S & $4.0 \pm 0$ & $S$ & $3.7 \pm 0.6$ \\
\hline 914 & S & $5.0 \pm 0$ & S & $5.0 \pm 0$ & M & $3.0 \pm 0$ & $\mathrm{R}$ & $2.0 \pm 0$ & M & $3.0 \pm 0$ \\
\hline 915 & S & $5.0 \pm 0$ & S & $4.0 \pm 0$ & $\mathrm{~S}$ & $4.7 \pm 0.6$ & M & $2.7 \pm 0.6$ & M & $3.0 \pm 0$ \\
\hline 916 & S & $5.0 \pm 0$ & S & $5.0 \pm 0$ & S & $5.0 \pm 0$ & $\mathrm{R}$ & $1.0 \pm 0$ & $\mathrm{R}$ & $2.0 \pm 0$ \\
\hline 917 & S & $5.0 \pm 0$ & S & $4.3 \pm 0.6$ & S & $5.0 \pm 0$ & S & $4.7 \pm 0.6$ & M & $3.0 \pm 0$ \\
\hline 918 & S & $5.0 \pm 0$ & S & $5.0 \pm 0$ & M & $3.0 \pm 0$ & $\mathrm{R}$ & 0 & $\mathrm{R}$ & $1.7 \pm 0.6$ \\
\hline 919 & S & $5.0 \pm 0$ & S & $4.7 \pm 0.6$ & S & $4.3 \pm 0.6$ & S & $4.3 \pm 0.6$ & S & $3.7 \pm 0.6$ \\
\hline 920 & S & $4.7 \pm 0.6$ & S & $4.3 \pm 0.6$ & $\mathrm{R}$ & $2.0 \pm 0$ & $\mathrm{R}$ & $2.0 \pm 0$ & M & $3.0 \pm 0$ \\
\hline 921 & S & $5.0 \pm 0$ & $\mathrm{~S}$ & $4.7 \pm 0.6$ & $\mathrm{R}$ & $2.0 \pm 0$ & $\mathrm{R}$ & 0 & $\mathrm{R}$ & 0 \\
\hline 922 & M & $3.0 \pm 0$ & $\mathrm{M}$ & $3.0 \pm 0$ & M & $2.3 \pm 0.6$ & M & $3.0 \pm 0$ & M & $3.0 \pm 0$ \\
\hline 923 & S & $4.0 \pm 0$ & $\mathrm{~S}$ & $3.7 \pm 0.6$ & S & $4.0 \pm 0$ & M & $3.0 \pm 0$ & M & $3.0 \pm 0$ \\
\hline 924 & S & $5.0 \pm 0$ & S & $4.3 \pm 0.6$ & S & $4.0 \pm 0$ & $\mathrm{R}$ & $2.0 \pm 0$ & M & $2.7 \pm 0.6$ \\
\hline 925 & S & $3.7 \pm 0.6$ & S & $3.7 \pm 0.6$ & S & $4.0 \pm 0$ & $\mathrm{R}$ & $2.0 \pm 0$ & S & $3.7 \pm 0.6$ \\
\hline 926 & S & $5.0 \pm 0$ & $\mathrm{R}$ & $1.0 \pm 0$ & $\mathrm{R}$ & $1.0 \pm 0$ & $\mathrm{R}$ & $1.0 \pm 0$ & $\mathrm{R}$ & $1.3 \pm 0.6$ \\
\hline 927 & S & $4.0 \pm 0$ & M & $3.0 \pm 0$ & M & $3.0 \pm 0$ & M & $3.0 \pm 0$ & M & $2.3 \pm 0.6$ \\
\hline 928 & S & $5.0 \pm 0$ & $\mathrm{~S}$ & $5.0 \pm 0$ & $\mathrm{~S}$ & $4.7 \pm 0.6$ & $\mathrm{R}$ & $1.0 \pm 0$ & $\mathrm{R}$ & $2.0 \pm 0$ \\
\hline 929 & S & $4.0 \pm 0$ & $\mathrm{R}$ & $1.0 \pm 0$ & S & $4.7 \pm 0.6$ & $\mathrm{R}$ & $1.0 \pm 0$ & M & $3.0 \pm 0$ \\
\hline 930 & S & $4.0 \pm 0$ & $\mathrm{R}$ & $1.0 \pm 0$ & M & $3.0 \pm 0$ & $\mathrm{R}$ & 0 & $\mathrm{R}$ & $1.0 \pm 0$ \\
\hline 931 & S & $5.0 \pm 0$ & S & $4.7 \pm 0.6$ & $\mathrm{~S}$ & $4.7 \pm 0.6$ & $\mathrm{R}$ & $1.0 \pm 0$ & $\mathrm{R}$ & $2.0 \pm 0$ \\
\hline 932 & S & $5.0 \pm 0$ & S & $4.0 \pm 0$ & S & $5.0 \pm 0$ & S & $4.0 \pm 0$ & S & $4.0 \pm 0$ \\
\hline 933 & S & $5.0 \pm 0$ & S & $5.0 \pm 0$ & S & $5.0 \pm 0$ & $\mathrm{R}$ & $2.0 \pm 0$ & M & $3.0 \pm 0$ \\
\hline 934 & S & $5.0 \pm 0$ & S & $4.7 \pm 0.6$ & $\mathrm{~S}$ & $5.0 \pm 0$ & $\mathrm{R}$ & $2.0 \pm 0$ & S & $4.7 \pm 0.6$ \\
\hline 935 & $S$ & $4.3 \pm 0.6$ & S & $3.7 \pm 0.6$ & M & $3.0 \pm 0$ & M & $3.0 \pm 0$ & $\mathrm{R}$ & $2.0 \pm 0$ \\
\hline 936 & S & $4.0 \pm 0$ & $\mathrm{R}$ & $1.7 \pm 0.6$ & M & $3.0 \pm 0$ & $\mathrm{R}$ & 0 & M & $3.0 \pm 0$ \\
\hline 937 & S & $5.0 \pm 0$ & S & $5.0 \pm 0$ & $\mathrm{R}$ & 0 & $\mathrm{R}$ & 0 & $\mathrm{R}$ & $2.0 \pm 0$ \\
\hline 938 & $\mathrm{~S}$ & $5.0 \pm 0$ & S & $4.3 \pm 0.6$ & S & $4.7 \pm 0.6$ & M & $3.0 \pm 0$ & $\mathrm{R}$ & $1.0 \pm 0$ \\
\hline 939 & S & $5.0 \pm 0$ & S & $5.0 \pm 0$ & S & $4.0 \pm 0$ & $S$ & $3.7 \pm 0.6$ & S & $3.7 \pm 0.6$ \\
\hline 940 & $S$ & $4.7 \pm 0.6$ & $S$ & $4.0 \pm 0$ & $S$ & $4.0 \pm 0$ & M & $3.0 \pm 0$ & $\mathrm{M}$ & $3.0 \pm 0$ \\
\hline
\end{tabular}

${ }^{1}$ Scale of symptoms types: 0 = no symptoms; 1 = few small flecks $(1 \mathrm{~mm}) ; \mathbf{2}=$ flecks $2-3 \mathrm{~mm}$, limited lesions; 3 = coalescent flecks, lesions 4-7 mm; $4=$ water-soaked lesions, higher than $7 \mathrm{~mm} ; 5=$ spreading coalescent lesions with sporulation. Averages (three repetitions, three replicates each) of the non-transformed scores, were categorized into three broad reaction classes: Resistant (R: $\leq$ 2), Moderately Resistant (M: 2.1-3.0) and Susceptible (S: $>3.0)$. ${ }^{2}$ Scale of disease severity: $0=$ no necrotic tissue (NT); $1=\leq 5 \%$ NT; $2=6-20 \%$ NT; $3=21-35 \%$ NT; $4=36-60 \%$ NT; $5=61-100 \%$ NT. Averages (three repetitions, three replicates each) of the nontransformed data $\leq 2.0$ suggested low aggressiveness, and $>3.0$ suggested high aggressiveness. 
Table 3 - Analysis of variance for the average disease severity scores (transformed data $\sqrt{x+0.5}$ ), of three repetitions with three replicates each, on young detached first leaves (abaxial surface) of different clones of Anacardium occidentale, $120 \mathrm{~h}$ after inoculation with different isolates of Colletotrichum gloeosporioides in controlled environment.

\begin{tabular}{lrcccc}
\hline Source & DF & SS & MS & VR (F) & Tab. F (1\%) \\
\hline Clones & 4 & 33.67942 & 8.41986 & $946.2330 * * * 3715$ \\
Isolate & 35 & 25.20646 & 0.72018 & $80.0798 * * *$ & 1.6938 \\
Clones x Isolates & 140 & 37.32995 & 0.26664 & $29.6664 * *$ & 1.3746 \\
Treatments & 179 & 96.21583 & 0.53752 & $59.7686 * *$ & 1.3434 \\
Error & 360 & 3.23760 & 0.00899 & & \\
Total & 539 & 99.45343 & CV $=4.91784 \%$ & LSD for clones $=0.21$ & LSD for isolates $=0.30$ \\
\hline
\end{tabular}
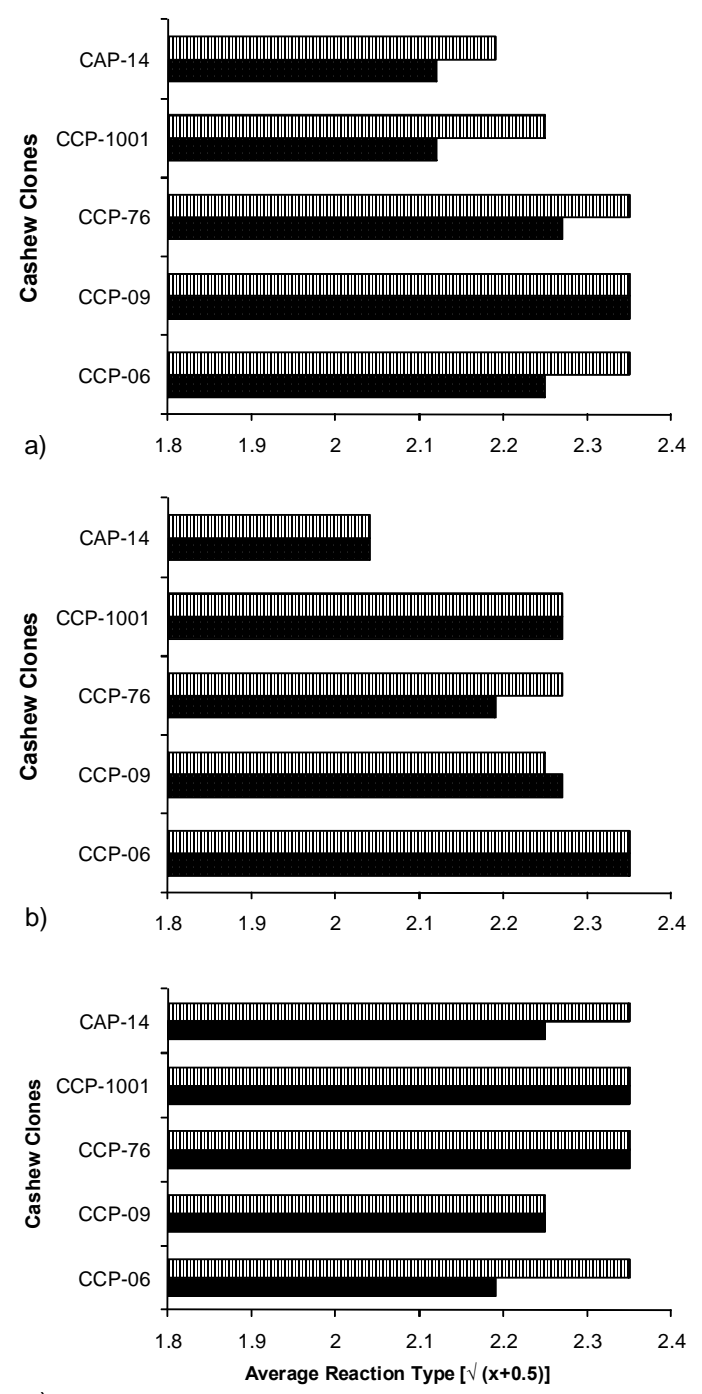

c) In 1st detached wounded leaves 2 nd detached wounded leaves

Figure 2 - Disease severity on the first (1st) and second (2nd) detached and injured leaves of Anacardium occidentale clones, $120 \mathrm{~h}$ after inoculation (abaxial surface) with LARS isolates of Colletotrichum gloeosporioides: a) 905; b) 910; c) 912. Averages (three experiments in triplicates) of the transformed data $\leq 1.58$ (type 2) were scored as resistant; from 1.58 to 1.87 (types 2 and 3) as moderately resistant, and $>1.87$ (type 3 ) as susceptible.
Although the abaxial surface of young cashew leaves has a higher number of stomata (ca. 60,000-100,000 $\mathrm{cm}^{-2}$ ) and trichomes $\left(c a .3,000 \mathrm{~cm}^{-2}\right)$ than the adaxial surface (no stomata and ca. 1,000. $\mathrm{cm}^{-2}$ trichomes) (Ohler, 1979), which might suggest easier fungal penetration and infection in the former, inoculation of the later gave similar disease severity. Then, albeit penetration via stomata and cells beneath trichomes in young leaves occurs in cashew, it does not play the special role as it does in some other host-C. gloeosporioides interactions, such as tea, rubber and northern jointvetch (Ando and Hamaya, 1986; Senéchal et al., 1987; Tebeest et al., 1978).

Furthermore, as older cashew leaves have a tougher texture and higher number of trichomes on the adaxial surface than its younger leaves (Shaper and Chacko, 1991), and they are less susceptible to anthracnose, the few sites of infection may be due to invasion through injuries and stomatal openings. Perennial evergreen plants of resource-poor environments tend to have high levels of immobile defences, such as waxy cuticle, thick epidermis, tannins, flavonoids and lignins in the outer epidermal cell wall of leaves and in the outer cortical tissues of stems, without the metabolic costs of turnover. There is a correlation between structural barriers/tannin levels and the relative vulnerability of such plants to certain pathogens (Edwards, 1992).

Penetration through wounds have also been identified as essential for C. musae to cause crown and finger stalk rot in banana, for C. gloeosporioides to cause dieback in cassava, or for G. cingulata f. sp. camelliae to cause leaf blotch, canker and dieback in Camellia species (Van der Bruggen and Maraite, 1987; Waller, 1992). Van der Bruggen et al. (1990) found that C. gloeosporioides can penetrate tissues of a resistant cultivar of cassava through a puncture made either by a hot needle or an insect (Pseudotheraptus devastans). Infection of cashew by C. gloeosporioides in the field is often preceded by infestation with the insect Helopeltis antonii Müller (Varma and Balasundaran, 1990).

The five dwarf cashew clones used in this work were included in the field trials reported by Cardoso et al. (1999), when these authors evaluated disease levels on dwarf cashew clones over two seasons in Brazil, but their performance differed slightly, once that CAP-14 was the most resistant and CCP-09 the most susceptible in the 
field. This probably happened because of the phenology of the crop, and the timing of leaf emergence (flushing) and blossoming. With CAP-14, for instance, the flushing and blossom phase preceded the main rainfall season, which is favourable for infection and epidemic spread. Hence, disease escape may play a critical role in addition to the genetic resistance of leaves to the pathogen.

The fact that isolates from host species other than cashew (LARS 905-909) were able to cause anthracnose in this plant is not a new observation for $C$. gloeosporioides. Several authors have reported cross-infections in controlled environmental conditions with Colletotrichum isolates from many fruit crops (Abang et al., 2006; Serra et al., 2008; Xiao et al., 2004). In some instances, isolates from different hosts had identical rDNA and similar mtDNA banding patterns (Alahakoon et al., 1994), while heterogeneity was observed within populations of $C$ gloeosporioides on almond, apple, avocado, mango and strawberry, all of which possess a teleomorphic stage (Freeman et al., 1998). Furthermore, a heterothallic isolate from pecan, able to infect apple, was found to mate with isolates of C. gloeosporioides $\mathrm{f}$. sp. aeschynomene, a mycoherbicide of northern jointvetch weed (Cisar et al., 1994).

Polymorphism of the D2 sequences of the $28 \mathrm{~S}$ rDNAs of the 36 isolates studied in the present work (data not shown) had high homology between themselves and with C. gloeosporioides from distantly-related hosts, being not enough to clearly distinguish inside the species [the four sub-groups of isolates have origins as distant as Rubus brasiliensis (LARS 905), Dioscorea sp.
(LARS 908), Malpighia glabra (LARS 909), Spondias purpurea L. (LARS 906), Carica papaya (LARS 907) and A. occidentale (LARS 910)]. But they were all able to infect different clones of cashew, providing evidences for the anthracnose cross-infection in cashew.

\section{Pathogenicity assays with fruits and pseudofruits}

The detached ripened pseudo-fruits (apples) of the commercial clones were all susceptible to isolates 905 and 910. A quiescent infection was verified on immature apples (except for the clone CCP-76), while immature nuts were more susceptible than mature ones (Table 4). In most tropical unripened fruits, C. gloeosporioides initially gains entry through the cuticle, but it is further restricted within the epidermal layer in a latent or dormant form. It is only able to colonise the tissues after fruit ripening, when host-physiological changes stimulate further pathogen development (Prusky and Plumbley, 1992).

The high content of tannins in cashew pseudo-fruit peel decreases with maturity (Wardowski and Ahrens, 1990). Tannins and their oxidation products are effective inhibitors of fungal enzymes, and epicatechin (tannin) from the pericarp of unripe resistant avocado fruits inhibits endopolygalacturonase, pectate-lyase and lipoxygenase (LOX) produced by C. gloeosporioides. Decay by C. gloeosporioides in post-harvest avocado is related to the degradation of an antifungal diene, which is catalyzed by LOX (Prusky and Plumbley, 1992; Wattad et al., 1994). Therefore, the concentration of tannins also plays a role in the restriction of anthracnose of young cashew pseudo-fruits.

Table 4 - Reaction class (RC) ${ }^{1}$ scores on pseudo-fruits and attached nuts of different clones of Anacardium occidentale at different stages of development, $96 \mathrm{~h}$ after inoculation with isolates 905 and 910 of Colletotrichum gloeosporioides in a controlled environment.

\begin{tabular}{|c|c|c|c|c|c|c|c|c|c|}
\hline \multirow{3}{*}{ Isolates } & \multirow{3}{*}{$\begin{array}{l}\text { Growth Stage } \\
\text { (weeks) }\end{array}$} & \multicolumn{8}{|c|}{ Clones } \\
\hline & & \multicolumn{2}{|c|}{ CCP-06 } & \multicolumn{2}{|c|}{ ССР-09 } & \multicolumn{2}{|c|}{ CCP-76 } & \multicolumn{2}{|c|}{ CCP-1001 } \\
\hline & & nut & pseudo-fruit & nut & pseudo-fruit & nut & pseudo-fruit & nut & pseudo-fruit \\
\hline \multirow{6}{*}{905} & 1 & $3.0 \pm 0 *$ & $2.0 \pm 0$ & $3.0 \pm 0 \%$ & 0 & $3.0 \pm 0 \%$ & $2.0 \pm 0$ & $3.0 \pm 0 \%$ & 0 \\
\hline & 2 & $3.0 \pm 0 *$ & $2.0 \pm 0$ & $3.0 \pm 0 \%$ & 0 & $3.0 \pm 0 \%$ & $3.3 \pm 0.6$ & $3.0 \pm 0 *$ & 0 \\
\hline & $3-4$ & $3.0 \pm 0 \%$ & $3.0 \pm 0$ & $3.0 \pm 0 \%$ & $2.0 \pm 0$ & $3.0 \pm 0 \%$ & $4.0 \pm 0$ & $3.0 \pm 0 *$ & $2.0 \pm 0$ \\
\hline & $5-6$ & $1.0 \pm 0 *$ & $3.0 \pm 0$ & $1.0 \pm 0 \%$ & $3.0 \pm 0$ & $1.0 \pm 0$ & $4.0 \pm 0$ & 0 & $3.0 \pm 0$ \\
\hline & 7-8 & 0 & $4.0 \pm 0$ & 0 & $4.0 \pm 0$ & $1.0 \pm 0$ & $4.0 \pm 0$ & 0 & $4.0 \pm 0$ \\
\hline & 9 & 0 & $5.0 \pm 0$ & 0 & $5.0 \pm 0$ & 0 & $5.0 \pm 0$ & 0 & $5.0 \pm 0$ \\
\hline \multirow{6}{*}{910} & 1 & $3.0 \pm 0 *$ & $0.7 \pm 0.30$ & $3.0 \pm 0 \%$ & 0 & $3.0 \pm 0 \%$ & $2.0 \pm 0$ & $3.0 \pm 0 *$ & 0 \\
\hline & 2 & $3.0 \pm 0 *$ & $1.0 \pm 0$ & $3.0 \pm 0 *$ & 0 & $3.0 \pm 0 \%$ & $3.7 \pm 0.6$ & $2.7 \pm 0.6 *$ & 0 \\
\hline & $3-4$ & $2.0 \pm 0 *$ & $1.6 \pm 0.6$ & $3.0 \pm 0 *$ & $0.3 \pm 0.6$ & $3.0 \pm 0 \%$ & $4.0 \pm 0$ & $3.0 \pm 0 *$ & $1.6 \pm 0.6$ \\
\hline & $5-6$ & 0 & $3.0 \pm 0$ & $1.0 \pm 0$ & $2.0 \pm 0$ & $1.0 \pm 0$ & $4.0 \pm 0$ & 0 & $2.7 \pm 0.6$ \\
\hline & $7-8$ & 0 & $3.0 \pm 0$ & 0 & $3.0 \pm 0$ & $1.0 \pm 0$ & $4.0 \pm 0$ & 0 & $3.0 \pm 0$ \\
\hline & 9 & 0 & $4.0 \pm 0$ & 0 & $4.0 \pm 0$ & 0 & $5.0 \pm 0$ & 0 & $4.7 \pm 0.6$ \\
\hline
\end{tabular}

${ }^{1}$ Average (three repetitions, three replicates each) of the non-transformed data (symptom type) based on a $0-5$ scale $[0=$ no symptoms; 1 = few small flecks $(1 \mathrm{~mm}) ; \mathbf{2}$ = flecks between $2-3 \mathrm{~mm} /$ limited lesions; 3 = coalescent flecks (lesions $4-7 \mathrm{~mm}) ; \mathbf{4}=$ watersoaked lesions $(>7 \mathrm{~mm}) ; \mathbf{5}=$ spreading lesions with sporulation]. Data were categorized into three three broad reaction classes: Resistant (R: $\leq 2.0)$, Moderately Resistant (M: 2.1-3.0) and Susceptible (S: >3).*Green Exocarp. 


\section{Conclusions}

Although under a standardised set of conditions only a narrow range of dwarf cashew clones (five) was tested, with a small sample of isolates (36) from cashew and intercropped plants from some Brazilian regions, the clone CCP-06 was the most susceptible, CCP-1001 was the most resistant and none of the clones were significantly resistant to all of the tested isolates. These isolates also varied in their virulence/ aggressiveness towards cashew, and it is unlikely that based on the differential reactions found the isolates can be grouped into subpopulations. The genetic basis of the quantitative control of the differential interactions identified is not currently known. More work analyzing field populations of the pathogen by genetic markers is required.

\section{Acknowledgements}

CAPES. IACR receives grant-aided support from the BBSRC (UK).

\section{References}

Abang, M.M.; Asiedu, R.; Hoffmann, P.; Wolf, G.A.; Mignouna, H.D.; Winter, S. 2006. Pathogenic and genetic variability among Colletotrichum gloeosporioides isolates from different yam hosts in the agroecological zones in Nigeria. Journal of Phytopathology 154: 51-61.

Alahakoon, P.W.; Brown, A.E.; Sreenivasaprasad, S. 1994. Crossinfection potential of genetic groups of Colletotrichum gloeosporioides on tropical fruits. Physiological and Molecular Plant Pathology 44: 93-103.

Ando, Y.; Hamaya, E. 1986. Defense reaction of the plant against infection of the tea anthracnose fungus. Study Tea 69: 35-43.

Barros, L.M.; Crisóstomo J.R. 1995. Breeding of the cashew. p. 7393. In: Araújo, J.P.P.; da Silva, V.V., eds. Cashew: Modern Production Techniques. EMBRAPA-CNPAT, Fortaleza, Brazil (in Portuguese).

Bentes, J.L.S.; Matsuoka, K. 2002. Histology of Colletotrichum guaranicola and Paullinia cupana var. sorbilis on resistant and susceptible clones. Fitopatologia Brasileira 27: 71-77 (in Portuguese, with abstract in English).

Cardoso, J.E.; Cavalcanti, J.J.V.; Cavalcanti, M.J.B.; Aragão, M.L.; Felipe, E.M. 1999. Genetic resistance to anthracnose, black mold, and angular leaf spot. Crop Protection 18: 23-27.

Cisar, C.R.; Spiegel, F.W.; Tebeest, D.O.; Trout, C. 1994. Evidence for mating between isolates of Colletotrichum gloeosporioides with different host specificities. Current Genetics 25: 330-335.

Edwards, P.J. 1992. Resistance and Defense: the role of secondary plant substances. p. 69-84. In: Aires, P.G., ed. Pests and Pathogens: Plant Response to Foliar Attack. Bioscience,, London, UK.

Freeman, S.; Katan, T.; Shabi, E. 1998. Characterization of Colletotrichum species responsible for anthracnose diseases of various fruits. Plant Disease 82: 596-605.
Freire, F.C.O.; Cardoso, J.E.; Santos, A.A.; Viana, F.M.P. 2002. Diseases of cashew nut plants (Anacardium occidentale L.) in Brazil. Crop Protection 21: 489-494.

Mathur, R.S.; Barnett, H.L.; Lilly, V.G. 1950. Sporulation of Colletotrichum lindemuthianum in culture. Phytopathology 40: 104-114.

Ohler, J.G. 1979. Cashew. Koninkjik Institut voor de Tropen., Amsterdam, Netherlands. 360 p. (Communication 71). .

Prusky, D.; Plumbley, R.A. 1992. Quiescent infections of Colletotrichum in tropical and subtropical fruits. p. 289-307. In: Bailey, J.A; Jeger, M.J., eds. Colletotrichum: Biology, Pathology and Control. CAB International, Wallingford, UK.

Senéchal, Y.; Sanier, C.; Gobet, E.; D'auzac, J. 1987. Different modes de penetration of C. gloeosporioides dans les feuilles d'Hevea brasiliensis. Comptes Rendus de L'Academie Science 305: 537-542.

Serra, I.M.S.; Coelho, R.S.B.; Menezes, M. 2008. Physiologic and pathogenic characterization, and isozyme analysis of monosporic and multisporic isolates of Colletotrichum gloeosporioides. Summa Phytopathologica 34: 113-120 (in Portuguese, with abstract in English).

Shaper, H.; Chacko, E.K. 1991. Effect of irradiance, leaf age, chlorophyll content and branch-girdling on gas exchange of cashew (Anacardium occidentale L.) leaves. Journal of Horticulture Science 68: 541-550.

Tebeest, D.O.; Templeton, G.E.; Smith Jr, R.J. 1978. Histopatology of Colletotrichum gloeosporioides $\mathrm{f}$. sp. aeschynomene on Northern Jointvetch. Phytopathology 68: 1271-1275.

Van der Bruggen, P.; Gregoire, D.; Maraite, H. 1990. Temperatureinduced alterations in the expression of susceptibility of cassava to Colletotrichum gloeosporiodes $\mathrm{f}$. sp. manihotis. Journal of Phytopathology 130: 46-58.

Van der Bruggen, P.; Maraite, H. 1987. Histopatology of cassava anthracnose disease caused by C. gloeosporioides f. sp. manihotis. Parasitica 43: 3-21.

Varma, R.V.; Balasundaran, M. 1990. Tea mosquito (Helopeltis antonii) feeding as a predisposing factor for entry of wound pathogens in cashew. Entomology 15: 249-251.

Waller, J.M. 1992. Colletotrichum diseases of perennial and other cash crops. p. 167-185. In: Bailey, J.A; Jeger, M.J., eds. Colletotrichum: Biology, Pathology and Control. CAB International, Wallingford, UK.

Wardowski, W.F.; Ahrens, M.J. 1990. Cashew apple and nut. p. 6787. In: Nagy, S.; Shaw, P.E.; Wardowski, W.F., eds. Fruit of Tropical and Subtropical Origin: Composition, Properties and Uses. FSS, Lake Alfred, FL, USA.

Wattad, C.A.; Dinoor, A.; Prusky, D. 1994. Purification of pectatelyase produced by Colletotrichum gloeosporioides and its inhibition by epicatechin a possible factor involved in the resistance of unripe avocado fruits to anthracnose. Molecular Plant- Microbe Interactions 7: 293-297.

Xiao, C.L.; Mackenzie, S.J.; Legard, D.E. 2004. Genetic and pathogenic analyses of Colletotrichum gloeosporioides isolates from strawberry and noncultivated hosts. Phytopathology 94: 446453.

Received September 19, 2008

Accepted January 20, 2010 